\title{
A Refined Mathematical Model of Physical Processes in a Conductor at a High-Current Pulse Discharge
}

\author{
Yevgen Bajda (D), and Michael Pantelyat (iD \\ National Technical University "Kharkiv Polytechnic Institute", Kharkiv, Ukraine
}

\author{
Article History \\ Received: \\ 08 October 2021 \\ Accepted: \\ 29 December 2021 \\ Published online: \\ 30 December 2021 \\ Keywords \\ Multiphysics Processes; \\ Thermal Strength; \\ Short-Term Electrical \\ Discharge; \\ Mathematical Model
}

\begin{abstract}
A novel mathematical model describing physical processes during the flow of an aperiodic pulse current with amplitude of $100 \mathrm{kA}$ along a conductor with a circular cross-section is proposed and investigated. It is shown how a short-term electric discharge of an aperiodic shape affects the distribution of the current density in the cross-section of the conductor, causing its nonuniform heating and the appearance of significant thermal forces as well as mechanical stresses and strains. Based on the developed mathematical model, the relationship between electromagnetic, thermal and mechanical phenomena is shown, allowing a deeper understanding of the multiphysics processes taking place. The maximum values of the current density are calculated, which on the surface of the conductor reach values of $47 \mathrm{kA} / \mathrm{mm}^{2}$, while the temperature rise of a copper conductor with a diameter of $2.44 \mathrm{~mm}$ is no more than $80^{\circ} \mathrm{C}$ at high temperature gradients, which causes the appearance of thermal stresses that have value $(40-50) \%$ of the value of the short-term strength limit of electrical copper. Utilization of this model allows to more accurately determine the required conductor cross-section based on the characteristics of electromagnetic, thermal and mechanical processes. It is shown that the simplified model (the condition for the uniform distribution of the current over the cross-section) gives significantly underestimated values of temperatures and does not take into account temperature deformations.
\end{abstract}

\section{INTRODUCTION}

Physical phenomena associated with the study of multiphysics processes occurring in conductors when pulse currents flow through them are relevant. This is confirmed by both International Standards [1, 2] and a number of publications [3-12]. To the greatest extent, this concerns the study of the processes occurring in conductors during high-current short-term electrical discharges, which are accompanied by a number of complex and interrelated physical phenomena [9-13].

The processes considered in [3-8] concern "the execution of an approximate calculation of the critical and maximum permissible cross-sections and current densities in wires and cables". In a number of cases, the calculations are based on the introduction of "normalizing coefficients", which are introduced when determining the Joule integral ("action integral" in these works). This approach is justified, which is confirmed experimentally, if the frequency of the processes is low: $50-400 \mathrm{~Hz}[6,7]$ (the penetration depth of the electromagnetic wave is greater than the transverse dimensions of the conductor). If we consider short-term pulse processes [3-5], then before using approximate formulas, it is necessary in each specific case to estimate the penetration depth of an electromagnetic wave, at least in a steady-state mode [10, 14], comparing it with the dimensions of the conductor.

It should be noted that powerful short-term pulses of current when flowing through a conductor cause a number of multiphysics phenomena: electromagnetic, thermal and mechanical ones. Electromagnetic processes are associated with the appearance of Lorentz forces, which exert a mechanical effect on the conductor. Nonuniform heating of the conductor leads to the appearance of significant temperature gradients [15] and forces associated with an nonuniform variation in volume. Heating also leads to a variation in the resistivity of the conductor, which in turn affects the distribution of the current density in the conductor, its heating and the

Corresponding author: yevhen.baida@khpi.edu.ua (Yevgen Bajda)

(c) 2021 The Author(s). Published by O. M. Beketov National University of Urban Economy in Kharkiv Use permitted under Creative Commons Attribution 4.0 International (CC BY 4.0)

Cite as: Bajda, Y., \& Pantelyat, M. (2021). A refined mathematical model of physical processes in a conductor at a highcurrent pulse discharge. Lighting Engineering \& Power Engineering, 60(3), 124-132. https://doi.org/10.33042/2079-424X. 2021.60.3.05 
distribution of electromagnetic and thermal forces. In $[11,12]$ the relationship of electromagnetic and thermal processes in a conductor is considered, but mechanical phenomena associated with electromagnetic and thermal processes are not taken into account.

The novelty of this paper lies in an integrated approach to the study of the thermal strength of a conductor when short-term pulse currents of significant amplitude $(100 \mathrm{kA})$ flow through it (duration is $60 \mu \mathrm{s}$ and the rate of rise of the front is $10^{4} \mathrm{~A} / \mu \mathrm{s}$ ), taking into account electromagnetic, thermal and mechanical processes, which was not considered earlier.

The goal of the paper is to clarify the physical processes and quantitatively estimate the parameters (electromagnetic, thermal and mechanical ones) when a high-current pulse discharge flows through a conductor on the basis of the developed mathematical model as well as to formulate and implement an approach to solving problems of this kind.

\section{BASIC PHYSICAL PROCESSES, CALCULATION RELATIONSHIPS AND ASSUMPTIONS}

The calculations are carried out for a round sufficiently long conductor of standard sizes which are shown in Fig. 1.

The wire is covered with insulation, as in [5], the conductor is made of copper, the maximum current value is $100 \mathrm{kA}$ [6]. The temporal shape of the discharge current (see Fig. 2)

$i(t)=I_{m} \cdot\left(e^{-a_{1} \cdot t}-e^{-a_{2} \cdot t}\right)$,

where $I_{m}$ is the maximum value; $a_{1}, a_{2}$ are the coefficients.

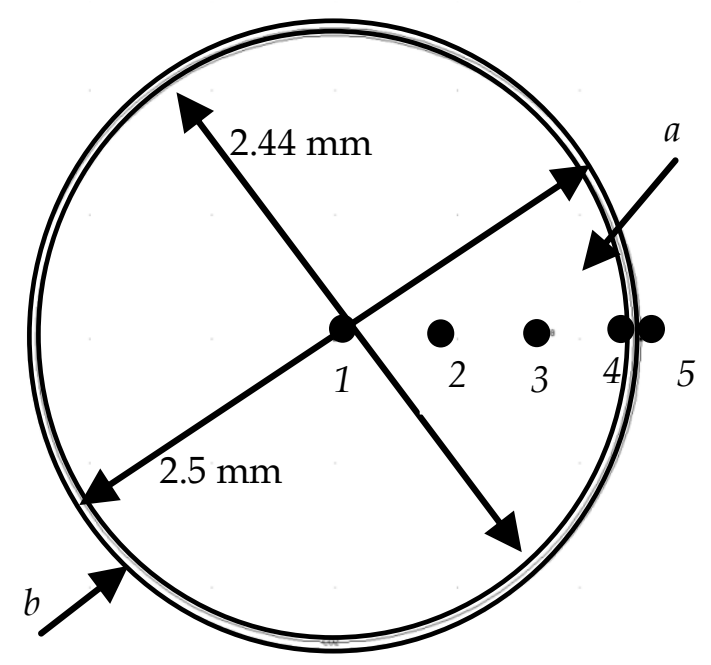

Figure 1. Shape of the conductor: $(a)$ is the wire; $(b)$ is the insulation; 1-5 are the designation of points for the analysis of results obtained

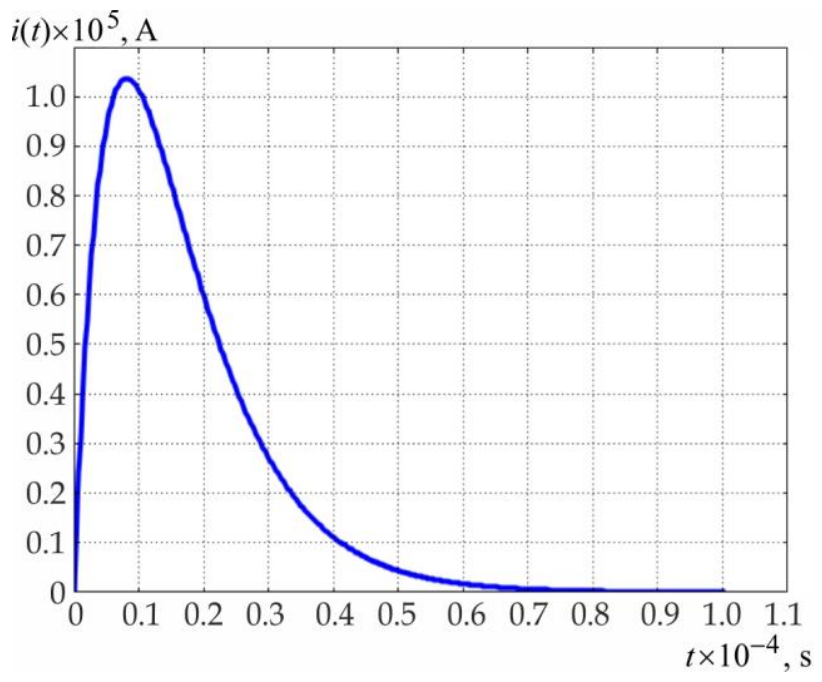

Figure 2. Temporal shape of the discharge current

\section{Main Physical Processes under Consideration}

The flow of pulse current through the conductor, accompanied by: nonuniform distribution of current over the cross-sectional area; nonuniform heat release over the cross-sectional area; appearance of significant Lorentz forces acting on the conductor.

Nonuniform heating of the conductor leads to: a nonuniform change in conductivity, which affects the distribution of the current density; occurrence of high temperature gradients and appearance of additional mechanical stresses, both in the conductor itself and at the conductor-insulation interface.

Mechanical deformations of the conductor material caused by electromagnetic and thermal effects.

As follows from the above, the first two processes are interconnected and significantly affect the mechanical forces in the conductor.

\section{CAlculation Assumptions}

Processes occurring in the conductor do not affect the value and shape of the acting current. The heating temperature of the conductor is less than $250^{\circ} \mathrm{C}$ and the effect of temperature on the elastic modulus of the material can be neglected.

\section{Main CALCUlation RELATIONSHIPS}

\section{Electromagnetic Field Distribution}

The equation of transient electromagnetic field in a conductor written in terms of the magnetic vector potential [16]:

$\sigma_{i}(T) \cdot \frac{\partial \mathbf{A}_{i}}{\partial t}+\frac{1}{\mu_{0}} \cdot \nabla \times\left(\nabla \times \mathbf{A}_{i}\right)=0$,

where $\sigma(T)$ is the specific electrical conductivity of the material depending on the temperature of the wire; $\mathbf{A}$ is the magnetic vector potential directed 
along the axis of the conductor; $\mu_{0}$ is the magnetic permeability of vacuum; $i=1,2$ is the number of the computational subdomain.

In Eq. (2) the right-hand side is missing. External current is specified by the boundary condition, displacement currents are not taken into account.

As shown in [17], it is incorrect to solve problem (2) for plane-parallel field, given the condition that the field is equal to zero at the outer boundary (it is necessary to take into account the return wire). Therefore, the boundary conditions are set in the following form: at the boundary of the conductor

$$
-\mathbf{n} \times \mathbf{H}=\mathbf{J}_{s z},
$$

where $\mathbf{n}$ is the normal to the surface; $\mathbf{H}$ is the magnetic field strength at the boundary of the conductor; $\mathbf{J}_{s z}$ is the surface current equal

$$
\mathbf{J}_{s z}=-\mathbf{e}_{\phi} \cdot\left(\frac{i(t)}{2 \cdot \pi \cdot R}\right),
$$

where $R$ is the conductor radius; $\mathbf{e}_{\phi}$ is the unit vector.

\section{Temperature Field Distribution}

Thermal conductivity equation [18]:

$C_{\rho i} \frac{\partial T_{i}}{\partial t}+\nabla \cdot\left(-k_{i} \cdot \nabla \cdot T_{i}\right)=Q_{i}$,

where $C_{\rho i}$ is the volumetric heat capacity of the $i$-th subdomain material; $T_{i}$ is the temperature; $k_{i}$ is the thermal conductivity; $Q_{i}$ is the volumetric power of internal heat sources.

Boundary conditions [18]:

$-\mathbf{n} \cdot\left(-k_{i} \cdot \nabla \cdot T_{i}\right)=0$

on the outer boundary and conditions of limited temperature on the axis of the conductor.

At the inner boundaries (conductor-insulation), the condition of the continuity of temperatures and heat fluxes is set, which is performed automatically when calculating by numerical methods.

\section{Mechanical State of Sstress and Strain}

The calculation of mechanical state of stress and strain is carried out on the basis of the equations of the theory of elasticity, written in the form of the Lamé equations [19]:

$$
\rho \cdot \frac{\partial^{2} \mathbf{u}}{\partial t^{2}}=(\lambda+\mu) \cdot \nabla \nabla \cdot \mathbf{u}+\mu \cdot \nabla^{2} \mathbf{u}+\mathbf{F}-K \cdot \nabla \cdot T,
$$

where $\rho$ is the density of the material; $\mathbf{u}$ is the vector of displacements; $\lambda, \mu$ are the Lamé coefficients;

$\mathbf{F}$ is the vector of volumetric forces (in this problem, such forces are the Lorentz forces which depend on time); $K=\alpha \cdot E /(1-2 \cdot v)$ is the coefficient taking into account the variation in volumetric forces during heating; $v$ is the Poisson ratio; $E$ is the modulus of elasticity; $\alpha$ is the coefficient of volumetric expansion of the material.

Boundary conditions: on the axis of the wire, the displacements are equal to zero; on the outer boundary the forces are equal to zero.

Eq. (6) describes wave processes in solids. But since the speed of propagation of deformation waves in copper [19]

$v \approx \sqrt{\frac{E}{\rho}} \approx 3500 \mathrm{~m} / \mathrm{s}$,

then the time constant of such a process is less than $0.4 \mu \mathrm{s}$ and the process can be considered as quasistatic, since the duration of the current change and the thermal inertia of the material are an order of magnitude longer.

\section{RESULTS OF CALCULATIONS AND THEIR ANALYSIS}

\section{Electromagnetic Field Distribution}

In Fig. 3 shown the current density distribution as a function of time. Fig. 4 shows a graph of changes in the current density along the radius of the conductor at fixed points in time. The graphs (Fig. 3, 4) clearly demonstrate the nonuniform distribution of the current over the cross-sectional area. The maximum current density reaches values of the order of $48 \mathrm{kA} / \mathrm{mm}^{2}$ at the surface of the conductor.

Voltage drop across the conductor at given current is calculated by the formula:

$U=\frac{d}{S} \cdot \iint_{S} E_{z} \cdot d S$

$J_{z} \times 10^{4}, \mathrm{~A} / \mathrm{mm}^{2}$

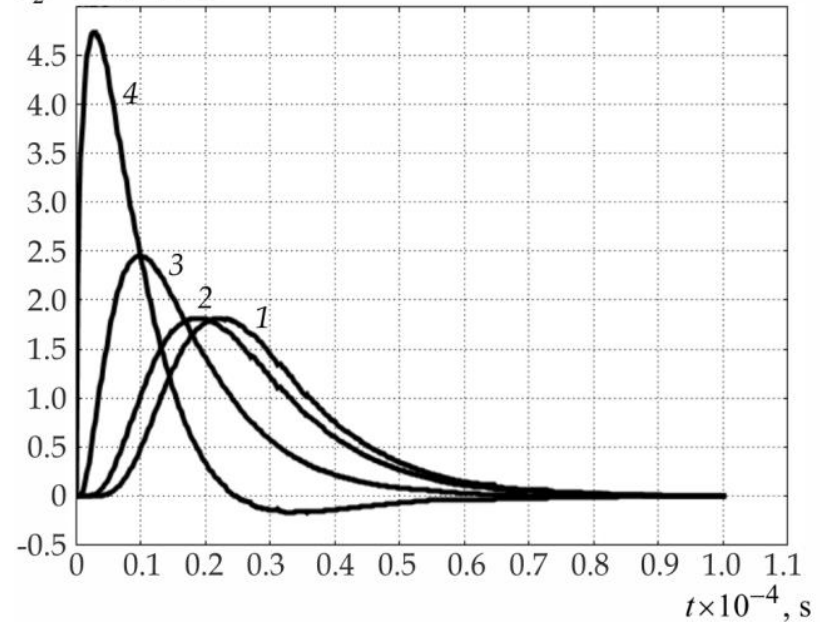

Figure 3. Temporal dependence of the current density: 1-4 are the points indicated in Fig. 1 


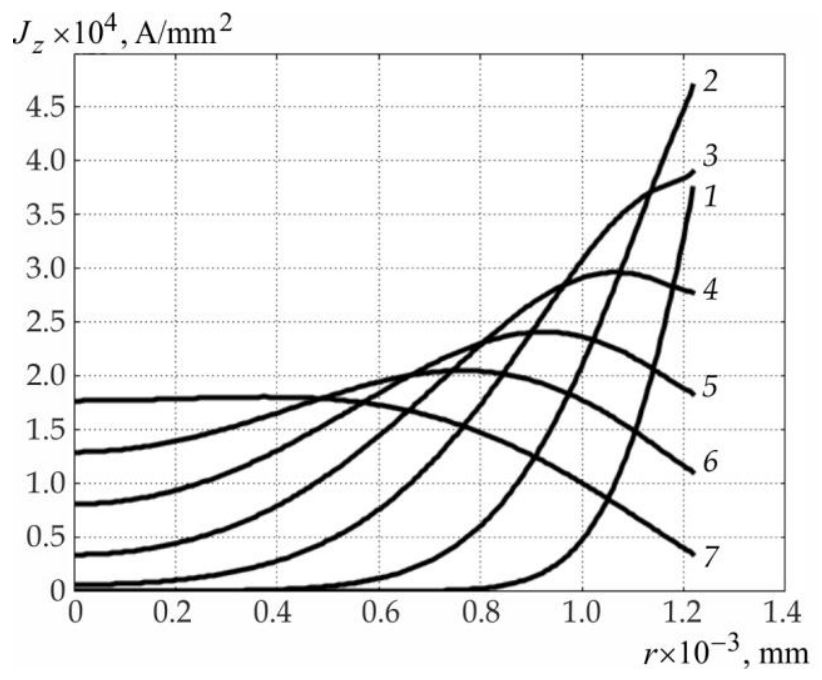

Figure 4. Current density distributions along the radius of the conductor at fixed points in time: $1-1 \mu \mathrm{s} ; 2-3 \mu \mathrm{s}$; $3-6 \mu \mathrm{s} ; 4-9 \mu \mathrm{s} ; 5-12 \mu \mathrm{s} ; 6-15 \mu \mathrm{s} ; 7-20 \mu \mathrm{s}$

where $U$ is the voltage drop; $S$ is the cross-sectional area; $d$ is the length; $E_{z}$ is the axial component of the electric field strength in the conductor.

The voltage distribution follows the current curve in shape, and the maximum value is $370 \mathrm{~V}$ along the conductor length of $1 \mathrm{~m}$.

\section{Temperature Field Distribution}

Obviously, at such high current densities, the power of volumetric heat sources is very high (the maximum value is about $4 \cdot 10^{13} \mathrm{~W} / \mathrm{m}^{3}$ ).

The distribution of power of heat sources along the radius of the conductor at fixed points in time is shown in Fig. 5.

From Fig. 5 it can be seen that the main thermal power is released within a short time in a thin outer layer of the conductor with thickness of about $0.4 \mathrm{~mm}$.

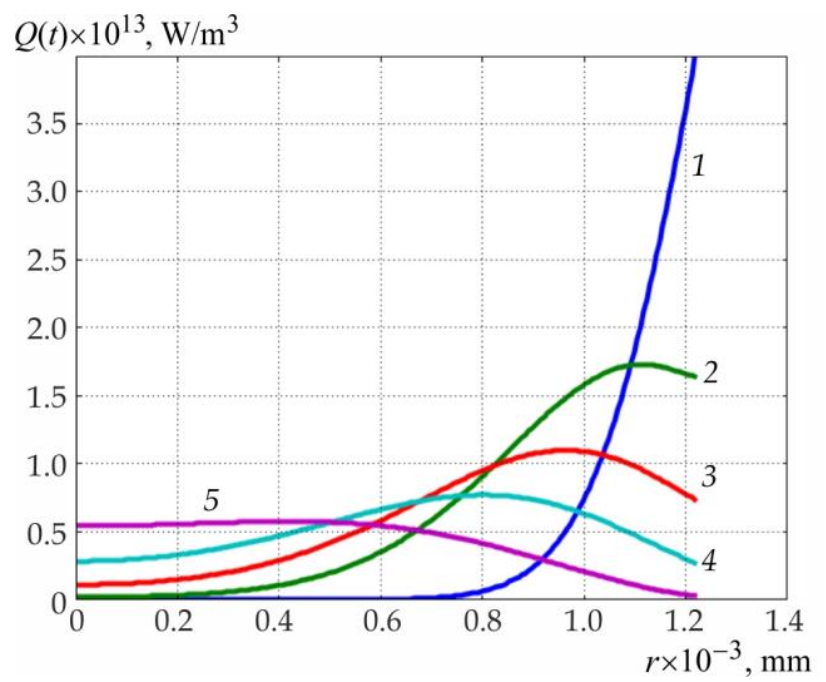

Figure 5. Distribution of internal heat sources power along the radius of the conductor at fixed points in time: $1-3 \mu \mathrm{s} ; 2-9 \mu \mathrm{s} ; 3-12 \mu \mathrm{s} ; 4-15 \mu \mathrm{s} ; 5-20 \mu \mathrm{s}$
The temperature rise over the cross-section of the conductor changes with some delay in relation to the power of the heat sources and, despite the small dimensions of the conductor, is nonuniformly distributed over the cross-section (see Fig. 6).

Fig. 6 implies the following: the heating of the conductor is small despite the significant current at the considered cross-sectional area; the outer surface of the conductor is heated to the greatest extent; during the current flow, the temperature of the outer surface of the insulation does not change. Despite the relatively small temperature rise, the temperature gradient that determines the mechanical forces in the conductor is quite large (see Fig. 7).

This temperature gradient (see Fig. 7) occurs on the surface of the conductor (conductor-insulation interface). Temperature gradients inside the conductor are orders of magnitude smaller. The maximum values (depending on the coordinates inside the conductor) vary in the range $(0.3-1.0) \cdot 10^{5} \mathrm{~K} / \mathrm{m}$.

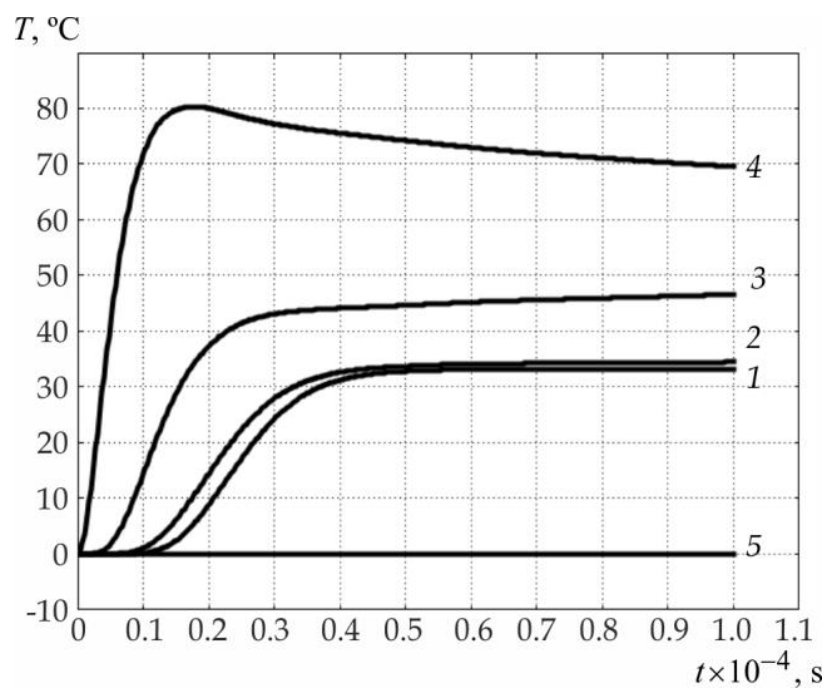

Figure 6. Temporal dependence of the temperature rise: 1-5 are the points indicated in Fig. 1

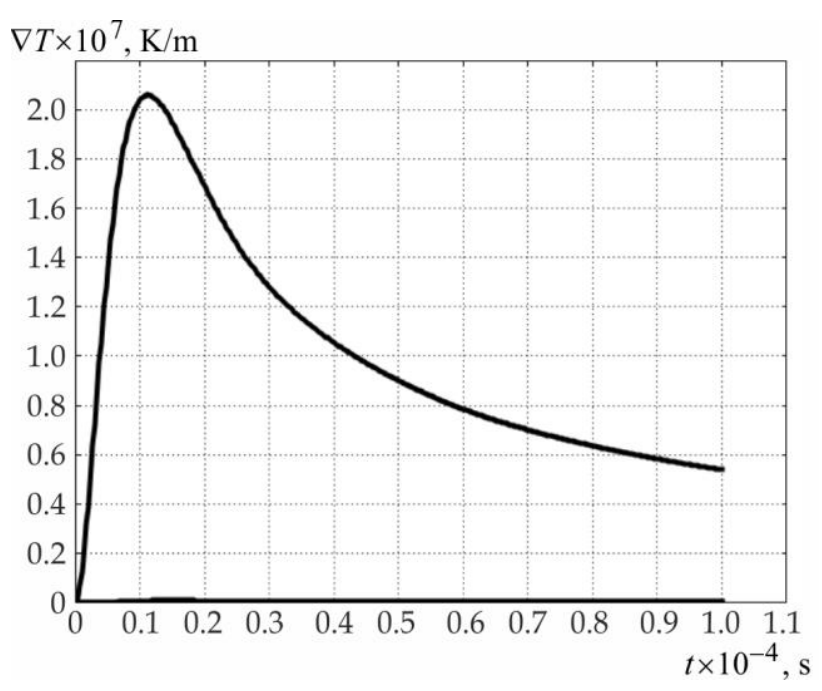

Figure 7. Temperature gradient on the surface of the conductor as a function of time 
Nevertheless, such gradients, in accordance with Eq. (6), cause mechanical deformations of the conductor and the appearance of mechanical stresses in its volume.

\section{Mechanical State OF STREsS and STRAin}

Fig. 8 shows the displacements of the points of the conductor (see Fig. 1) as a function of time. As follows from Fig. 8, first, under the action of the Lorentz forces, the conductor contracts, and then, under the influence of temperature, the conductor expands. In this problem, it is assumed that the insulation fits tightly to the conductor and changes dimensions with it. This can be in the case of soft insulation. In the event that the insulation is rigid, it is quite possible for it to peel off from the conductor and crack.

Despite the insignificance of the displacements, the stresses at the inner points of the conductor are quite large (see Fig. 9).

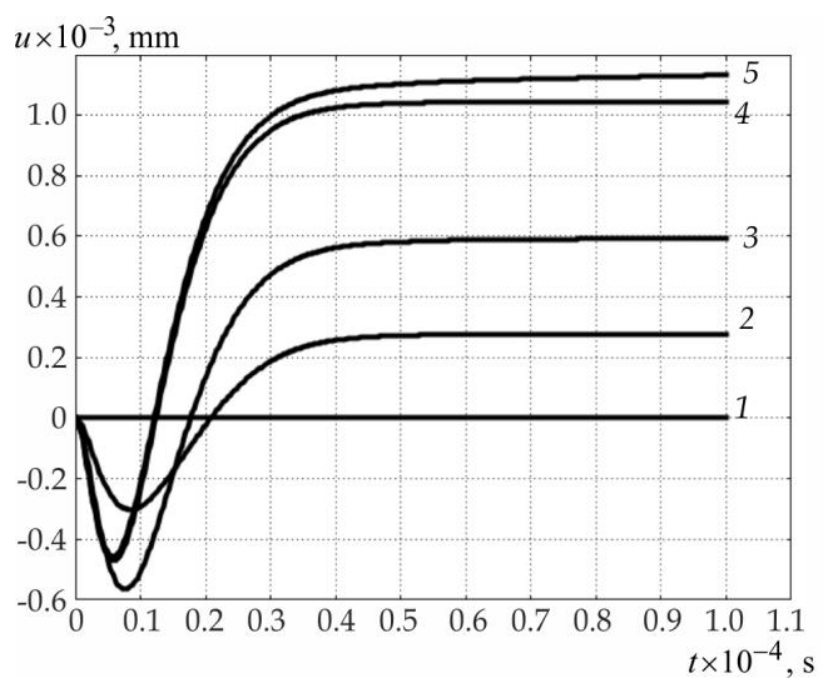

Figure 8. Radial displacement of the points of the conductor as a function of time: $1-5$ are the points indicated in Fig. 1

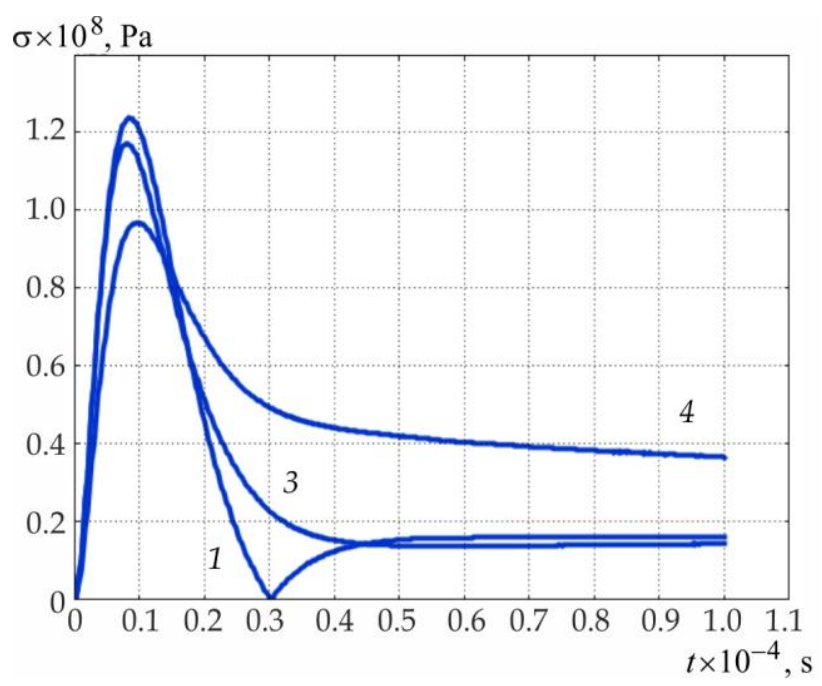

Figure 9. Von Mises stresses as a function of time: 1-4 are the points indicated in Fig. 1

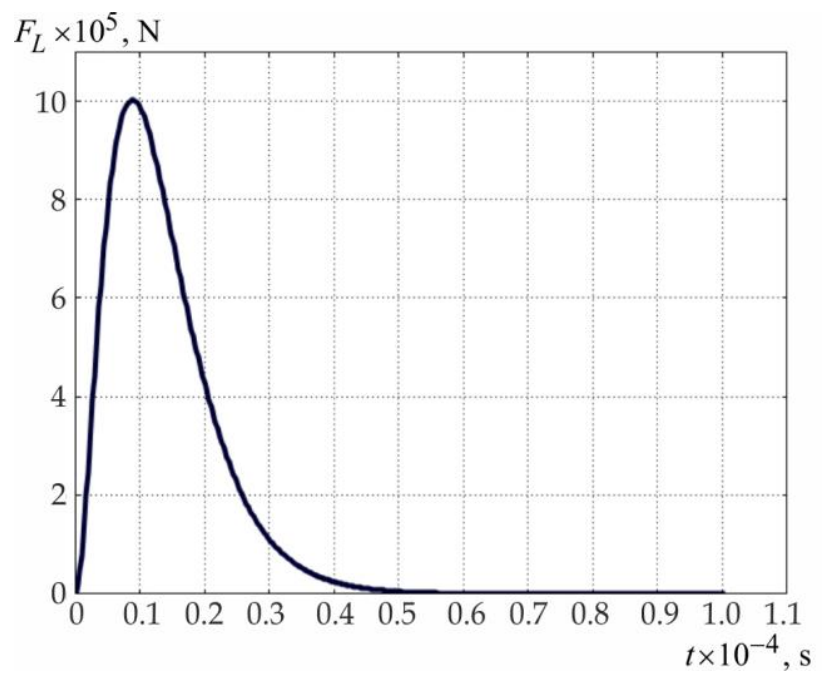

Figure 10. Lorentz force modulus on the surface of a wire $1 \mathrm{~m}$ long at pulse current

The obtained maximum values of mechanical stresses are of the same order as the short-term strength limit of electrical copper (200-250 MPa [20]) which decreases with increasing temperature.

Lorentz force acting on a wire of $1 \mathrm{~m}$ length is directed along the radius to the center of the conductor and is shown in Fig. 10.

From Fig. 10 it follows that the forces are sufficiently large and in the case of a hollow conductor its "collapse" at high currents can be observed.

\section{Calculation of the Heating of A CONDUCtor ASSUMING A UNIFORM CURRENT DISTRIBUTION OVER THE CROSS-SECTION}

The calculations described above are rather complicated. To check the possibility of carrying out a simplified calculation, we assume that there is a uniform (over the cross-section of the conductor) current density distribution. In this case, the temperature of the conductor can be determined by solving the equation:

$$
C_{\rho} \cdot \frac{d \vartheta(t)}{d t}=\left(\frac{i(t)}{S}\right)^{2} \cdot \rho_{0} \cdot\left(1+\alpha_{0} \cdot\left(\vartheta(t)-\vartheta_{0}\right)\right),
$$

where $C_{\rho}$ is the volumetric heat capacity; $S$ is the cross-sectional area; $\rho_{0}$ is the electrical resistivity at temperature $\vartheta_{0} ; \alpha_{0}$ is the temperature coefficient of resistance.

Solution of Eq. (9) with zero initial condition is shown in Fig. 11, which implies the following:

- the conductor is heated uniformly;

- no temperature gradients and mechanical stresses;

- the heating temperature of the conductor is two times less than the maximum one (see Fig. 6) and is equal to the steady-state temperature over the cross-section of the conductor. 


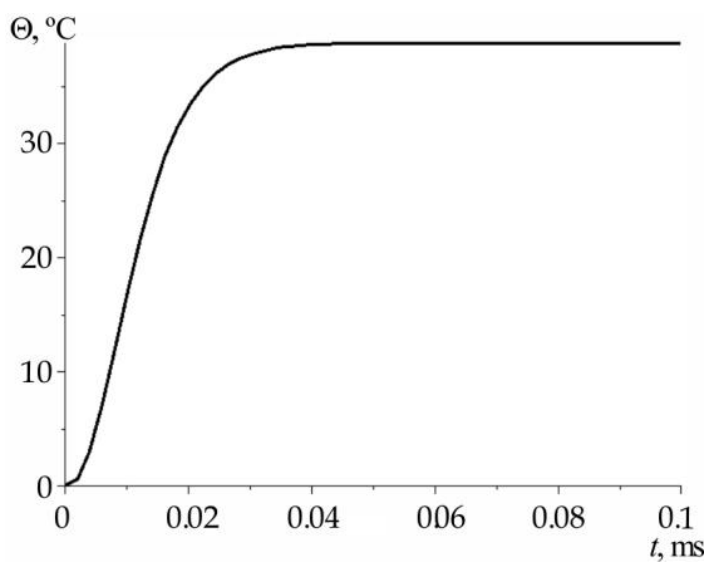

Figure 11. Temperature rise of the conductor under the assumption of a uniform distribution of the current density over the cross-section

Similar results are obtained if the temperature is calculated using the effective value of the current:

$$
I=\sqrt{\frac{1}{T} \cdot \int_{0}^{T} i(t)^{2} \cdot d t},
$$

where $T$ is the current action duration equal to $0.1 \mathrm{~ms}$.

Calculation according to Eq. (9) when substituting the value (10) gives the same $38.7^{\circ} \mathrm{C}$ for the time $T$ which is two times less than the maximum temperature.

\section{AN APPROXimate CALCUlation OF THE LORENTZ FORCES UNDER THE CONDITION OF A UNIFORM Distribution OF THE CURRENT OVER THE CROSS- SECTION}

It is known [13] that

$$
F_{L}=\int_{V} \mathbf{J} \times \mathbf{B} \cdot d V=-\mathbf{e}_{r} \cdot d \cdot \int_{V} J_{z} \cdot B_{\phi} \cdot d S,
$$

where $F_{L}$ is the Lorentz force; $\mathbf{B}$ is the vector of magnetic flux density; $\mathbf{e}_{r}$ is the unit vector; $d$ is the length of the conductor; $J_{z}$ is the current density; $B_{\phi}$ is the component of the magnetic flux density; $S$ is the cross-sectional area.

The minus sign in Eq. (11) means the compression of the conductor. With a uniform current density over the cross-sectional area of the conductor:

$J_{z}=\frac{i(t)}{\pi \cdot R^{2}}, B_{\phi}=i(t) \cdot \frac{r^{2}}{R^{2}} \cdot \frac{\mu_{0}}{2 \cdot \pi \cdot r}$,

where $R$ is the radius of the conductor, $r$ is the current value of the radius.

The result of integration is the expression:

$$
\left|F_{L}\right|=\frac{\mu_{0} \cdot i(t)^{2} \cdot d}{3 \cdot \pi \cdot R} .
$$

Fig. 12 shows a graph of the change in force with a conductor length of $1 \mathrm{~m}$.

As can be seen from the graphs in Fig. 10, 12, the values of the forces are almost the same, this is due to the fact that the Lorentz force depends on the current of the conductor, and not on its distribution over the cross-section.

However, when calculating significant deformations of a hollow conductor, it is necessary to take into account the volumetric distribution of forces and the nonuniform distribution of the current over the section, since this determines the strength properties of the material.

Such a calculation based on the developed model was carried out for a hollow conductor with diameter of $1.25 \mathrm{~mm}$ and wall thickness of $0.25 \mathrm{~mm}$ taking into account the dynamics of deformation and energy dissipation. Configuration changes and stress distribution at different points in time are shown in Fig. 13.

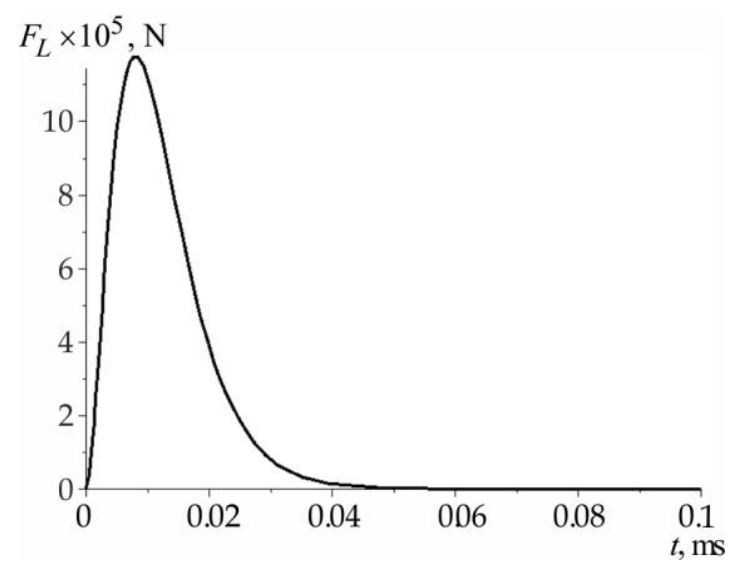

Figure 12. Lorentz force under the assumption of a uniform distribution of the current over the cross-section of the conductor

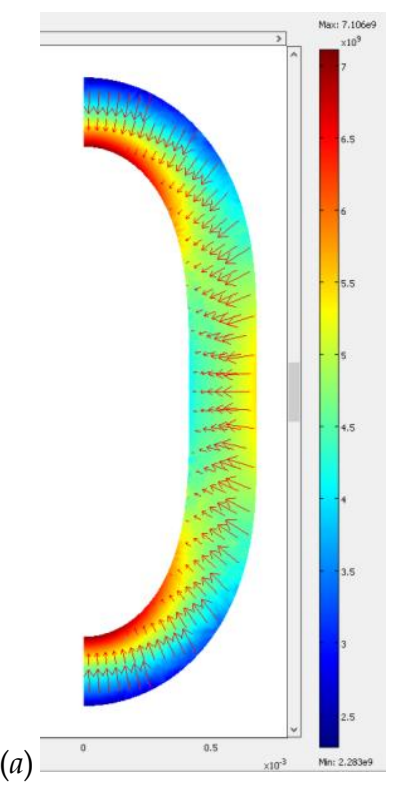

(b)

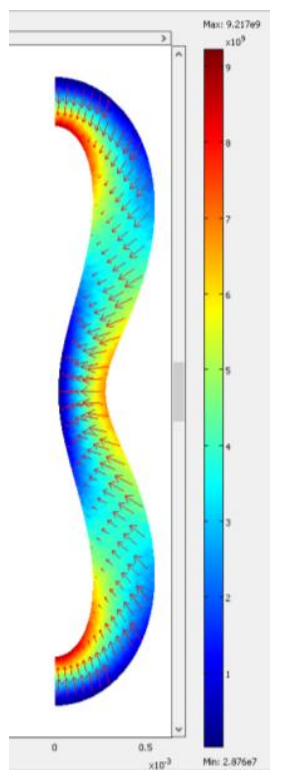

Figure 13. Change in the configuration of a round hollow conductor at current of $300 \mathrm{kA}$ in $5 \mu \mathrm{s}(a)$ and $13 \mu \mathrm{s}(b)$ 
Moreover, as it was found, the deformation is of a rather complex nature. Fig. 14 shows the horizontal and vertical deformations of points on the outer surface of the hollow cylinder.

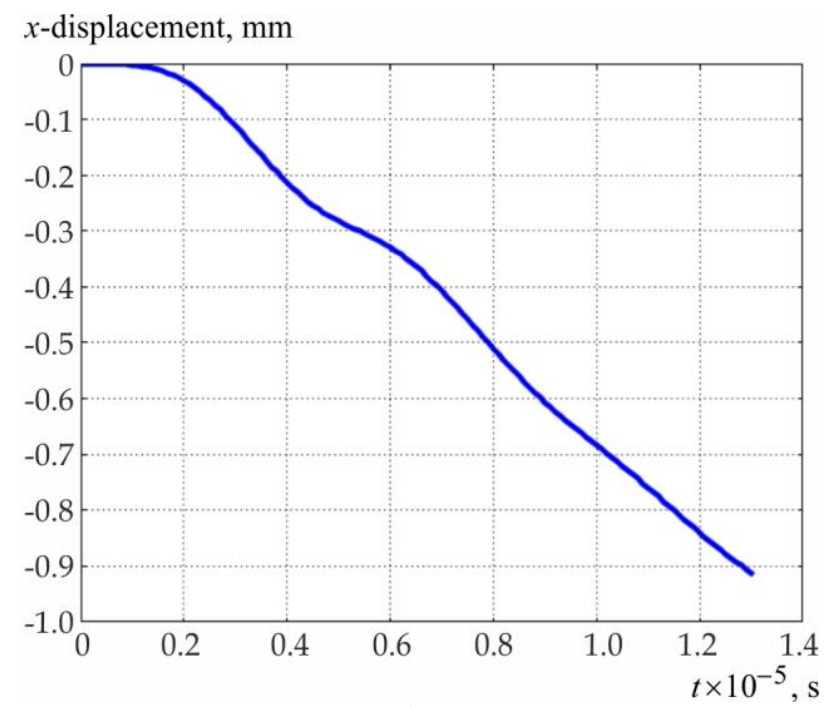

(a)

$y$-displacement, $\mathrm{mm}$

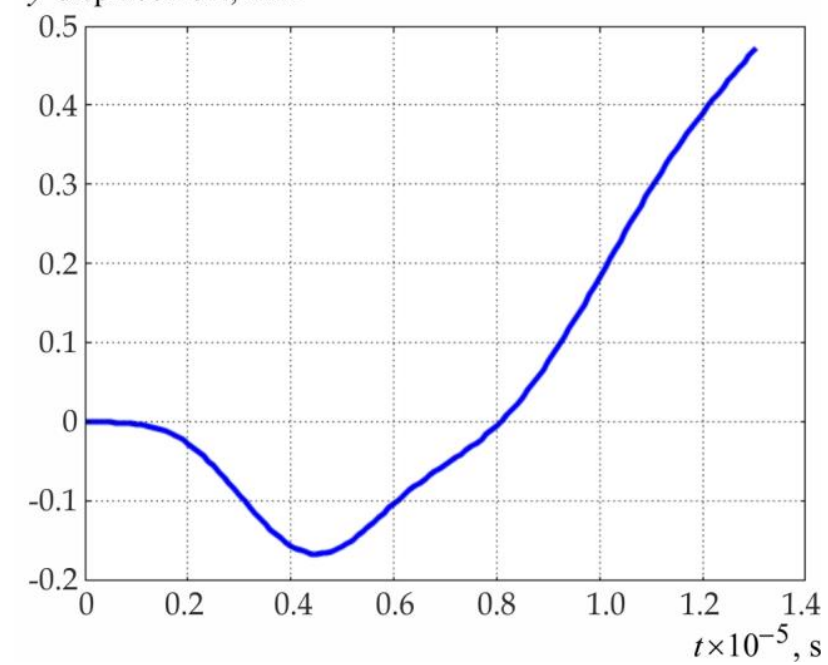

(b)

Figure 14. Horizontal ( $a$ ) and vertical $(b)$ deformation of a hollow conductor in $\mathrm{mm}$

Here, the deformation rate is high enough. The maximum values reach values of the order of $100 \mathrm{~m} / \mathrm{s}$ which implies a calculation taking into account the forces of inertia of the material.

\section{CONCLUSIONS}

A mathematical model of the processes arising from the flow of a high-current short-term current pulse of aperiodic shape along a round conductor is developed and investigated. The model allows, on the basis of refined calculations, to select the crosssection of the conductor, to determine the maximum temperature of its heating and the resulting me- chanical stresses. An algorithm for solving such problems is developed.

It is shown that the nonuniform distribution of the current density over the cross-section of the conductor determines the irregularity of its heating and the appearance of significant mechanical stresses. The values of the current density in the thin surface layer of the conductor reaches values of the order of $47 \mathrm{kA} / \mathrm{mm}^{2}$.

Mechanical forces acting on a conductor with current have a complex structure and are determined by both electromagnetic and thermal processes.

Prevailing both in time and in numerical values are the processes determined by the temperature gradient. Mechanical stresses are approximately 40$50 \%$ of the value of the short-term strength limit of the conductor material. Since the tensile strength is a function of temperature, mechanical deformation of the conductor can be observed at significant currents.

Calculation of the heating temperature of the conductor under the assumption of a uniform distribution of the current density over the crosssection with the investigated parameters of the current pulse leads to an error in determining the temperature. In addition, such a simplification assumes the same heating temperature of the conductor over the cross-section which makes it impossible to determine the thermal forces that affect the deformation of the conductor.

The values of the electromagnetic forces acting on the conductor under the assumption of a uniform distribution of the current density over the section gives results that practically coincide with the exact calculation, since the forces are determined by the total current of the conductor and weakly depend on its distribution over section.

For the current pulse under consideration, permissible in terms of thermal strength (the heating temperature rise of the copper conductor is $250^{\circ} \mathrm{C}$ at zero ambient temperature) is the value of the conductor diameter equals to $1.7 \mathrm{~mm}$. The assumption of a uniform distribution of the current density over the cross-section gives the calculated temperature value of $200^{\circ} \mathrm{C}$ which is a quarter less than the refined value.

The deformation of the conductor is nonuniform in directions, is of a complex nature and involves taking into account the forces of inertia arising in the deformable conductor.

\section{DISCLOSURE STATEMENT}

No potential conflict of interest was reported by the author(s). 


\section{REFERENCES}

1. SAE International. (2013). Aircraft lightning environment and related test waveforms (SAE Standard No. ARP5412B:2013). https://doi.org/10.4271/ARP5412B

2. SAE International. (2013). Aircraft lightning test methods (SAE Standard No. ARP5416A:2013). https:/ / doi. org/10.4271/ARP5416A

3. Baranov, M.I. (2018). A choice of sections of electric wires and cables in circuits of devices of high-voltage high-current impulse technique. Electrical Engineering $\mathcal{E}$ Electromechanics, (6), 56-62. https://doi.org/10.20998/ 2074-272X.2018.6.08

4. Baranov, M.I. (2019). Calculation and experimental determination of critical sections of electric wires and cables in the circuits of devices of high-voltage highcurrent pulse technique. Electrical Engineering \& Electromechanics, (2), 39-46. https://doi.org/10.20998/2074-272X. 2019.2.06

5. Baranov, M.I. (2019). Peculiarities of the manifestation and influence on the electromagnetic processes of the transient skin effect in metal conductors with pulsed current. Electrical Engineering \& Electromechanics, (4), 41-47. https://doi.org/10.20998/2074-272X.2019.4.06

6. Baranov, M.I. (2019). A choice of critical sections of electric wires and cables in power circuits of electrical equipment of power industry. Electrical Engineering $\mathcal{E}$ Electromechanics, (5), 35-39. https://doi.org/10.20998/ 2074-272X.2019.5.06

7. Baranov, M.I. (2020). A choice of acceptable sections of electric wires and cables in on-board circuits of aircraft electrical equipment. Electrical Engineering E Electromechanics, (1), 39-46. https://doi.org/10.20998/2074272X.2020.1.06

8. Baranov, M.I., Buriakovskyi, S.G., \& Kniaziev, V.V. (2021). Destruction of polymer insulation and threshold amplitudes of current pulses of different temporal shapes for electric wires and cables in the low- and high-current circuits of pulse power engineering, electrical engineering and electronic devices. Electrical Engineering \& Electromechanics, (6), 31-38. https://doi.org/10.20998/2074-272X. 2021.6.05
9. Kostiukov, I. (2021). Measurement of dissipation factor of inner layers of insulation in three-core belted cables. Lighting Engineering \& Power Engineering, 60(1), 2330. https:/ / doi.org/10.33042/2079-424X.2021.60.1.04

10. Gerling, D. (2009). Approximate analytical calculation of the skin effect in rectangular wires. In 2009 International Conference on Electrical Machines and Systems (pp. 16). IEEE. https://doi.org/10.1109/ICEMS.2009.5382786

11. Koller, L., Novák, B., \& Tevan, G. (2007). Heating effects of short-circuit current impulses on contacts and conductors - Part I. IEEE Transactions on Power Delivery, 23(1), 221-227. https://doi.org/10.1109/TPWRD.2007.90 5806

12. Hagglund, L., \& Sandstrom, J. (2003). Current Distribution in Conductors (Report No. 2003:5). Uppsala University. http://www.it.uu.se/edu/course/homepage/pr ojektF/vt03/projekt3.pdf

13. Mesiats, G.A. (2004). Pulse Power Engineering and Electronics. Nauka. (in Russian)

14. Waldow, P., \& Wolff, I. (1985). The skin-effect at high frequencies. IEEE Transactions on Microwave Theory and Techniques, 33(10), 1076-1082. https://doi.org/10. 1109/TMTT.1985.1133172

15. Voršič, Ž., Maruša, R., \& Pihler, J. (2019). New method for calculating the heating of the conductor. Energies, 12(14), 2769. https:/ / doi.org/10.3390/en12142769

16. Ramo, S., \& Whinnery, J.R. (1964). Fields and Waves in Modern Radio (2nd ed.). John Wiley \& Sons.

17. Baida, E.I. (2015). Peculiarities of calculation of magnetic systems with short-circuited secondary windings in in-plane formulation. Electrical Engineering E Electromechanics, (5), 18-22. https://doi.org/10.20998/2074272X.2015.5.02 (in Russian)

18. Carlslaw, H.S., \& Jaeger, J.C. (2011). Conduction of Heat in Solids (2nd ed.). Oxford University Press.

19. Timoshenko, S.P., \& Goodier, J.N. (2008). Theory of Elasticity (3rd ed.). McGraw-Hill.

20. Kuhn, H.-A., Altenberger, I., Käufler, A., Hölzl, H., \& Fünfer, M. (2012). Properties of high performance alloys for electromechanical connectors. In L. Collini (Ed.), Copper Alloys - Early Applications and Current Performance Enhancing Processes (pp. 51-68). IntechOpen. https://doi. org/10.5772/35148

\section{Уточнена математична модель фізичних процесів у провіднику при сильноточному імпульсному розряді}

\section{Євген Байда, Михайло Пантелят}

Анотація. У статті запропоновано та досліджено оригінальну математичну модель, що описує фізичні процеси при протіканні імпульсного струму аперіодичної форми великої амплітуди 100 кА по круглому в перетині провіднику. Показано як короткочасний електричний розряд впливає на розподіл густини струму в поперечному перетині провідника, викликаючи його нерівномірний нагрів і появу значних термічних сил. На основі розробленої математичної моделі показано взаємозв'язок між електромагнітними, тепловими та механічними явищами, що дозволяє глибше зрозуміти мультифізичні процеси, що відбуваються. Розраховані максимальні значення густини струму, які на поверхні провідника досягають значень 47 кА/мм², при цьому перевищення температури мідного провідника діаметром 2,44 мм становить не більше $80^{\circ} \mathrm{C}$ при великих градієнтах температури, що викликає появу термічних сил, які мають значення (40-50)\% від величини межі короткочасної міцності електротехнічної міді. Використання даної моделі дозволяє більш точно визначити необхідний поперечний перетин провідника та зрозуміти процеси руйнування ізоляції на підставі характеристик електромагнітних, теплових та механічних процесів. Доведено, що спрощена модель (умова рівномірного розподілу струму по перетину) дає 
істотно занижені значення температур, які в два рази менші, ніж максимальна температура при нерівномірній густини струму і не враховує температурні деформації.

Ключові слова: мультифізичні процеси, термічна стійкість, короткочасний електричний розряд, математична модель.

\section{NOTES ON CONTRIBUTORS}

Yevgen Bajda

yevhen.baida@khpi.edu.ua

Michael Pantelyat

mykhailo.panteliat@khpi.edu.ua
D.Sc., Associate Professor

Department of Electrical Apparatus

National Technical University “Kharkiv Polytechnic Institute”, Kharkiv, Ukraine

(iD) https://orcid.org/0000-0003-0297-328X

SC https:// scopus.com/authid/detail.uri?authorId=57201899539

Ph.D., Associate Professor

Department of Electrical Apparatus

National Technical University "Kharkiv Polytechnic Institute", Kharkiv, Ukraine

iD https://orcid.org/0000-0002-1357-2134

SC https://www.scopus.com/authid/detail.uri?authorId=6603090024 